\title{
INTESTINAL PARASITIC INFECTION, DEMOGRAPHIC STATUS OF SCHOOL CHILDREN AND SANITARY CONDITIONS OF SCHOOLS IN PATNA, BIHAR- A PILOT STUDY
}

\author{
Namrata Kumari ${ }^{1}$, Ashish Kumar², Sanjay Kumar³, Shailesh Kumar ${ }^{4}$, Anima Xess5 ${ }^{5}$, S. K. Shahi ${ }^{6}$ \\ ${ }^{1}$ Additional Professor, Department of Microbiology, Indira Gandhi Institute of Medical Sciences, Patna. \\ 2Intern, Indira Gandhi Institute of Medical Sciences, Patna. \\ ${ }^{3}$ Professor, Department of Community Medicine, Indira Gandhi Institute of Medical Sciences, Patna. \\ ${ }^{4}$ Additional Professor, Department of Microbiology, Indira Gandhi Institute of Medical Sciences, Patna. \\ 5 Professor, Department of Microbiology, Indira Gandhi Institute of Medical Sciences, Patna. \\ ${ }^{6}$ Professor and HOD, Department of Microbiology, Indira Gandhi Institute of Medical Sciences, Patna.
}

\section{ABSTRACT}

\section{BACKGROUND}

There are several localities in India from where scanty or no epidemiological information about prevalence of intestinal parasite among school children is available. Hence, the study was conducted to find out the prevalence and distribution of intestinal parasites and its correlation with demographic features of school children and sanitary conditions of schools of two different localities of Patna, Bihar.

\section{MATERIALS AND METHODS}

It was a comparative descriptive type of study. Two schools, one from posh and other from slum area were randomly selected. Seventy-five children from each school were selected by systematic random sampling within a duration of three months. Child form and school sanitary information form were used for demographic, parasitic and sanitary survey. Stool samples were examined by direct microscopic examination- saline and Lugol's iodine wet mount preparation. Chi-square test of statistical significance was applied to study the association between prevalence of intestinal parasites and demographic factor.

\section{RESULTS}

Total prevalence of parasites in study was $30.7 \%$ with higher prevalence in the slum area school. There was no statistically significant difference ( $p>0.05$ ) between two groups for intestinal infections, but numerical difference was definitely there.

\section{CONCLUSION}

The prevalence of intestinal parasite in slum area school was more than posh area school due to poor hygiene habits among children and poor sanitary conditions of slum area school.

\section{KEYWORDS}

Intestinal Parasitic Infections, Sanitary Conditions, School, Children.

HOW TO CITE THIS ARTICLE: Kumari N, Kumar A, Kumar S, et al. Intestinal parasitic infection, demographic status of school children and sanitary conditions of schools in Patna, Bihar- A pilot study. J. Evolution Med. Dent. Sci. 2017;6(56):4167-4171, DOI: $10.14260 /$ Jemds/2017/903.

\section{BACKGROUND}

The World Health Organisation (WHO) estimates that about 3.5 billion people are infected and approximately 450 million people face morbidity and occasional mortality due to intestinal helminths and protozoan parasites worldwide with the children being affected the most. ${ }^{1}$ The high prevalence of these infections is closely correlated with poverty, poor environmental hygiene and impoverished health services. ${ }^{1,2}$

According to the latest estimated report, more than 880 million children are in need of treatment for parasitic infections. ${ }^{3}$

The intestinal parasites are among the most common infection of school age children in developing countries. ${ }^{4,5}$

Financial or Other, Competing Interest: None.

Submission 23-06-2017, Peer Review 05-07-2017,

Acceptance 08-07-2017, Published 13-07-2017.

Corresponding Author:

Dr. Namrata Kumari,

Additional Professor, Department of Microbiology,

Indira Gandhi Institute of Medical Sciences (IGIMS),

Sheikhpura-14, Patna.

E-mail:nrainrai@gmail.com

DOI: $10.14260 /$ jemds $/ 2017 / 903$

\section{(c) $(1) \subseteq$}

As a result, they are at risk of detrimental effects like poor cognitive performance and poor physical growth.5,6 Many studies support the fact that once antiparasite treatment is administered, infected children show a dramatic increase in their long and short-term memory as well as their reasoning capacity and reading comprehension. School absenteeism drops by as much as $25 \% .{ }^{7}$ Lack of knowledge of prevalence of parasites in a particular geographical area may lead to misdiagnosis of intestinal parasitic infections as appendicitis and other inflammatory bowel diseases. ${ }^{8}$ Although, studies have been conducted on the prevalence of intestinal parasites among school children in India, there are still several localities from where scanty or no epidemiological information is available.4,9,10,11 The same is true for Bihar also.

The present pilot study was planned with the objective to find out the prevalence and distribution of intestinal parasites among the school children of two different localities of Patna, Bihar, and evaluate the demographic features of the school children, sanitary conditions of the schools and their correlation with the mentioned findings. Such epidemiological surveys are important since they reflect sanitary conditions of schools/area and generate data that is essential to formulate strategies for control of these infections in the region. ${ }^{12,13}$ 


\section{MATERIALS AND METHODS}

This comparative descriptive pilot study was conducted at two primary schools randomly selected one from posh and other from slum area of Patna, Bihar. Seventy-five children from each school were selected by systematic random sampling within a duration of three months (from mid-June to mid-September 2015). Children of both sex and between 613 years of age group were taken. Children who refused to participate in the study and those who failed to return the container with sample were excluded from the study. Finally, only 117 children could be included in the study.

\section{Sample Collection and Data Collection Procedure}

The purpose of the study and the procedure for stool sample collection was explained to school children, teachers and/or their parents in each school and informed written consent was taken.

A wide mouth leak proof plastic container marked with an identification number with the name of the subject was distributed to each enrolled child. One stool sample was collected from each child. Stool samples were examined within 2 hours of collection for trophozoites, cysts and ova of intestinal parasites by direct microscopic examination saline and Lugol's iodine wet mount preparation. Result was recorded on the child form. A child form with columns for child's name, sex, age, school grade, hygiene habits and type of parasitic infection was used during the survey.

The survey team observed school sanitation condition also during the surveys. The condition of water supply, condition of latrines, presence of soaps on the basins and presence of garbage piles around the school was investigated and recorded during the survey.

The data was entered into the computer using SPSS Version 7.5 and analysed. Chi-square test of statistical significance was applied to study the association between prevalence of intestinal parasites and the demographic factors. P values $<0.05$ was considered as significant.

The infected children were given one dose of albendazole (400 mg) once and metronidazole (200 $\mathrm{mg}$ ) three times a day for 7 days.

Institute Ethics Committee (IEC) approval was obtained to do the study.

\section{RESULTS}

Out of 150 containers distributed, 117 (78\%) were returned back with samples. The compliance among posh area school children was $84 \%$ and that among slum area school children was $72 \%$.

\section{Demographic Status}

Number of children was highest in 8-9 yrs. of age group (Figure 1, 2). Number of female children in slum area school was significantly higher as compared to number of male children (Figure 2). Mother's literacy was lower in families of slum area school children (Table 1(a)).

\section{Family Status}

Family head was either unemployed or daily labourer in slum area (Table 1(a)), whereas all the family head were employed from posh area. As assumed, most of the mothers were illiterate in slum area (Table 1(b)).

\section{Hygiene Habits}

Use of sanitary latrines, materials used for washing hand after defecation, use of chappal/shoes and general habits of children is shown in Table 2(a), 2(b), 2(c) and 2(d) respectively of both the study groups.

\section{Parasitic Infection}

A total of 63 children from posh area school and 54 children from slum area school were examined for intestinal parasites. Out of which $28.5 \%$ samples from posh area school children and $33.3 \%$ of samples from slum area school children were found to be positive for one or more parasites (Table 3). So, the total prevalence of intestinal parasites in study was $30.7 \%$.

The double infections were found only among slum area school children (Table 3). In posh area school, only Giardia infection was found, whereas in slum area school, Giardia lamblia and Hymenolepis nana were equally and most commonly found. In posh area school, only cysts of Giardia were found in all positive samples and in slum area school, one-third of positive samples had trophozoite and two-third had cyst stage of the parasite. The prevalence was further analysed according to age and sex of school children (Table 4). There was higher prevalence among female children in both schools. More infective cases were seen among age group of 8-9 yrs.

\section{After Analysis, it was found that-}

- Age and sex wise, there was significant difference $(\mathrm{p}<0.05)$ among children of posh area school and slum area school.

- Prevalence wise, there was no significant difference ( $p>0.05$ ) between two groups. But, numerical difference was definitely there.

\section{Sanitation Status}

Different parameters of sanitation conditions in posh and slum area schools is shown in Table 5.

\begin{tabular}{|c|c|c|}
\hline Mother's Literacy & $\begin{array}{c}\text { No. of Children in } \\
\text { Posh Area (n=63) }\end{array}$ & $\begin{array}{l}\text { No. of Children in } \\
\text { Slum Area (n=54) }\end{array}$ \\
\hline Illiterate & 5 & 51 \\
\hline Jp to middle school & 45 & 3 \\
\hline Above high school & 13 & 0 \\
\hline \multicolumn{2}{|c|}{ Table 1(a). Mother's Literacy in Families } \\
of Posh and Slum Area School Children
\end{tabular}

$\mathrm{P}<0.00, \mathrm{x}^{2}=87.36$

\begin{tabular}{|c|c|c|}
\hline $\begin{array}{c}\text { Occupation of } \\
\text { Family Head }\end{array}$ & $\begin{array}{c}\text { No. of Children in } \\
\text { Posh Area (n=63) }\end{array}$ & $\begin{array}{c}\text { No. of Children in } \\
\text { Slum Area (n=54) }\end{array}$ \\
\hline Unemployed & 0 & 15 \\
\hline Daily labourer & 0 & 30 \\
\hline Employed & 63 & 9 \\
\hline \multicolumn{2}{|r|}{ Table 1(b). Occupation of Family Head of } \\
Posh and Slum Area School Children
\end{tabular}

$\mathrm{P}<0.000, \mathrm{x}^{2}=85.34$. 


\begin{tabular}{|c|c|c|}
\hline $\begin{array}{c}\text { Use of Sanitary } \\
\text { Latrines }\end{array}$ & $\begin{array}{c}\text { No. of Children in } \\
\text { Posh Area (n=63) }\end{array}$ & $\begin{array}{c}\text { No. of Children in } \\
\text { Slum Area (n=54) }\end{array}$ \\
\hline $\begin{array}{c}\text { Children using } \\
\text { sanitary latrines }\end{array}$ & 63 & 39 \\
\hline $\begin{array}{c}\text { Children not using } \\
\text { sanitary latrines }\end{array}$ & 0 & 15 \\
\hline \multicolumn{2}{|c|}{ Table 2(a). Use of Sanitary Latrines by } \\
Children of Posh and Slum Area School \\
\hline
\end{tabular}

$\mathrm{P}<0.00, \mathrm{x}^{2}=17.66$

\begin{tabular}{|c|c|c|}
\hline $\begin{array}{c}\text { Material Used for } \\
\text { Washing Hand After } \\
\text { Defecation }\end{array}$ & $\begin{array}{c}\text { No. of Children } \\
\text { in Posh Area } \\
(\mathbf{n = 6 3 )}\end{array}$ & $\begin{array}{c}\text { No. of Children in } \\
\text { Slum Area (n=54) }\end{array}$ \\
\hline With soap and water & 63 & 42 \\
\hline With water only & 0 & 12 \\
\hline Table 2(b). Materials Used for Washing Hands After \\
Defecation by Children in Posh and Slum Area Schools \\
\hline
\end{tabular}

$\mathrm{P}<0.00, \mathrm{x}^{2}=17.74$.

\begin{tabular}{|c|c|c|}
\hline $\begin{array}{c}\text { Use of } \\
\text { Chappal/Shoes }\end{array}$ & $\begin{array}{c}\text { No. of Children in } \\
\text { Posh Area (n=63) }\end{array}$ & $\begin{array}{c}\text { No. of Children in } \\
\text { Slum Area (n=54) }\end{array}$ \\
\hline $\begin{array}{c}\text { Children using } \\
\text { chappal/shoes }\end{array}$ & 63 & 39 \\
\hline $\begin{array}{c}\text { Children walking } \\
\text { barefoot }\end{array}$ & 0 & 15 \\
\hline \multicolumn{2}{|c|}{ Table 2(c). Use of Chappal/Shoes by } \\
Children of Posh and Slum Area Schools \\
\hline
\end{tabular}

$\mathrm{P}<0.00, \mathrm{x}^{2}=16.66$

\begin{tabular}{|c|c|c|}
\hline $\begin{array}{c}\text { Nail, Cloths, Oral } \\
\text { Hygiene, etc. }\end{array}$ & $\begin{array}{c}\text { No. of Children in } \\
\text { Posh Area (n=63) }\end{array}$ & $\begin{array}{c}\text { No. of Children in } \\
\text { Slum Area (n=54) }\end{array}$ \\
\hline Appear tidy & 51 & 30 \\
\hline Appear untidy & 12 & 24 \\
\hline \multicolumn{2}{|c|}{ Table 2(d). General Habits of Children } \\
of Posh and Slum Area Schools
\end{tabular}

$\mathrm{P}<0.002, \mathrm{x}^{2}=7.65$.

\begin{tabular}{|c|c|c|}
\hline Infection & $\begin{array}{c}\text { No. of Children } \\
\text { in Posh Area } \\
\text { School (\%) } \\
(\mathbf{n = 6 3 )}\end{array}$ & $\begin{array}{c}\text { No. of Children in } \\
\text { Slum Area School } \\
\text { (\%) (n=54) }\end{array}$ \\
\hline Overall infection & $18(28.5)$ & $18(33.3)$ \\
\hline Double infection* & 0 & $9(16.7)$ \\
\hline Giardia lamblia & $18(28.5)$ & $9(16.7)$ \\
\hline Hymenolepis nana & 0 & $9(16.7)$ \\
\hline Trichuris trichiura & 0 & $6(11.7)$ \\
\hline Entamoeba histolytica & 0 & $3(5.5)$ \\
\hline \multicolumn{2}{|c|}{ Table 3. Prevalence of Intestinal Parasitic } \\
Infection in Posh and Slum Area School Children \\
\hline
\end{tabular}

*Double infections- Hymenolepis nana + Trichuris trichiura $=6$. Giardia lamblia + Entamoeba histolytica $=3$.

$\mathrm{P}<0.08, \mathrm{X}^{2}=1.74$

\begin{tabular}{|c|c|c|c|}
\hline $\begin{array}{c}\text { Age Group } \\
\text { and Sex }\end{array}$ & $\begin{array}{c}\text { \% of Children } \\
\text { in Posh Area } \\
\text { School (n=18)* }\end{array}$ & $\begin{array}{c}\text { \% of Children in } \\
\text { Slum Area School } \\
\text { (n=18)* }\end{array}$ & \multirow{2}{*}{ P Value } \\
\cline { 1 - 2 } 6-7 yrs. & 27.7 & 16.6 & \multirow{2}{*}{ P $<0.05$} \\
\cline { 1 - 3 } 8-9 yrs. & 61.1 & 50.0 & \\
\cline { 1 - 3 } 10-11 yrs. & 11.1 & 16.6 &
\end{tabular}

\begin{tabular}{|c|c|c|c|}
\hline $12-13$ yrs. & 0 & 16.6 & \\
\hline Male & 33.3 & 16.6 & \multirow{2}{*}{$\mathrm{P}<0.05$} \\
\hline Female & 66.6 & 83.3 & \\
\hline \multicolumn{4}{|c|}{$\begin{array}{c}\text { Table 4. Prevalence of Intestinal Parasitic Infection } \\
\text { According to Age Groups and Genders of Children in Posh } \\
\text { and Slum Area Schools }\end{array}$} \\
\hline
\end{tabular}

*only 18 children each from posh and slum area school were infected.

\begin{tabular}{|c|c|c|}
\hline Sanitary Condition & $\begin{array}{c}\text { Posh Area } \\
\text { School }\end{array}$ & $\begin{array}{c}\text { Slum Area } \\
\text { School }\end{array}$ \\
\hline Source of water supply & $\begin{array}{c}\text { Community } \\
\text { water supply }\end{array}$ & Hand pump \\
\hline Presence of water purifier & Present & Absent \\
\hline Condition of latrines & Clean & Dirty \\
\hline Soap on basin & Present & Absent \\
\hline Garbage piles around & Absent & Present \\
\hline Surrounding of school & Clean & Dirty \\
\hline Drainage of waste water & Close & Open \\
\hline \multicolumn{2}{|c|}{ Table 5. Description of Sanitation } \\
\multicolumn{2}{|c}{ Conditions in Posh and Slum Area Schools } \\
\hline
\end{tabular}

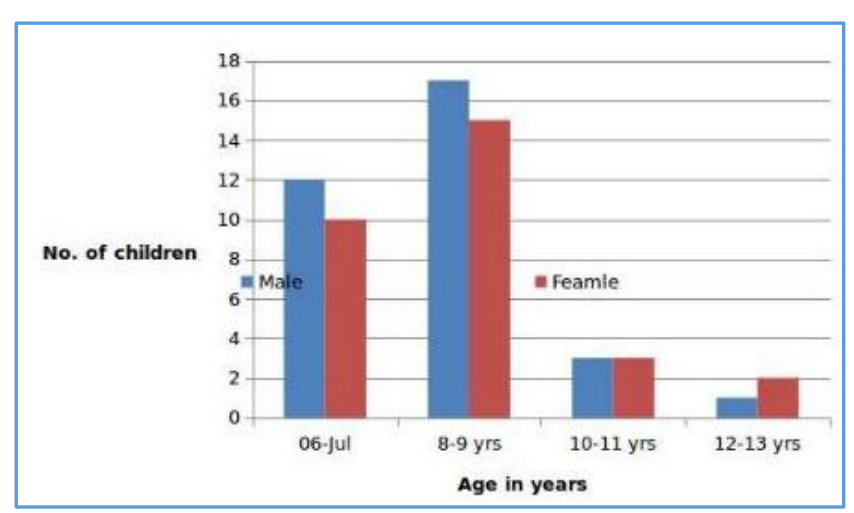

Figure 1. Showing Age Distribution and Sex Ratio among Posh Area School Children

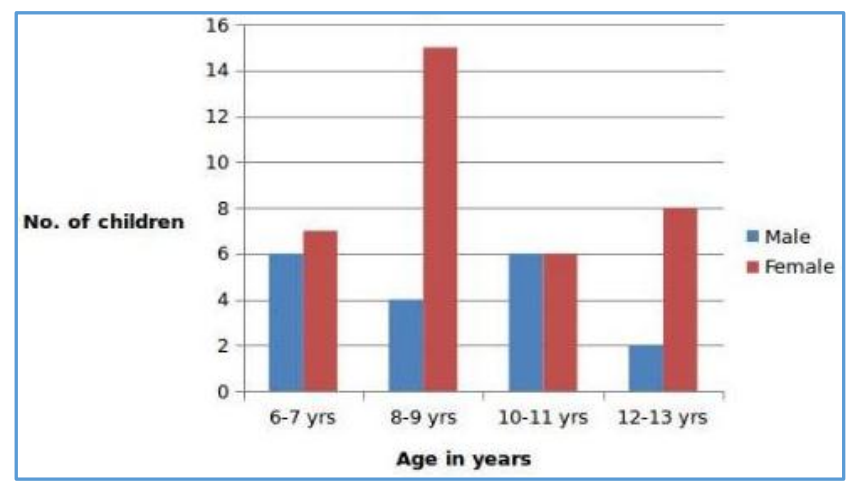

Figure 2. Showing Age Distribution and Sex Ratio among Slum Area School Children

\section{DISCUSSION}

The demographic data indicated that number of school children decreases as their ages rise in Posh Area School (PAS), whereas in the slum area school the number of children was almost same in all age groups. It may be due to the fact that children from posh area school tend to go to some better, more reputed posh area high school, whereas to the Slum Area School Children (SASC), there is no such option. But, this finding among SASC is quite encouraging as it indicates that the awareness about education benefits is increasing. 
The next demographic characteristic in Slum Area School (SAS) is that the number of female children attending the school doubling the number of male children is also encouraging as it again reflects increasing awareness about female literacy.

These demographic features are contrary to the findings of some studies from African and Islamic countries.5,14 The total prevalence of parasite among the school children (posh + slum) was found to be $30.7 \%$, which is quite less as compared to a study from Punjab (68\%), but nearly collaborates with the finding from western Nepal $(21.3 \%)$ and Lucknow (38.41\%).12,15,16 The prevalence of different parasitic infections was found to be associated with age factor. This finding goes with the finding of study by Kaur $\mathrm{H}$ et al. ${ }^{15}$ The higher prevalence of infection in SASC may be explained due to poor socioeconomic status and literacy of parents, poor hygiene habits and lack of sanitation facilities as suggested by other studies.5,15 Survey team observed that toilets were poorly sanitised and there was no soap on the basin. Garbage piles were accumulated around the school and schoolchildren were digging and playing on it. Thus, the children may have been exposed to additional risk of transmission of infection.

The Posh Area School Children (PASC) also suffered substantial infection rate (28.5\%), although their school was better sanitised and the parents were in better socioeconomic condition. This may be due to whole urban areas being at risk of infection as they eat raw vegetables, which were grown by night soil in the city. The most common parasite found in both the school was Giardia lamblia (Total23.1\%; PAS- $28.5 \%$ and SAS- $16.7 \%$ ) in cyst or trophozoite form. It corroborates with the finding from Chandigarh. ${ }^{17}$ No helminth was found from PASC, whereas protozoa as well as helminths both were found in SASC. It maybe correlated with good hygiene habits and sanitation conditions in PASC, whereas SASC lacked it. In addition, the slum area school children might be contracting it, also due to drinking water source being hand pump located near waste drainage and water coming out from high level (10-20 feet), which is easily contaminated with surface runoff and seepage.

The infection rate of Entamoeba histolytica was very less in the study. It was found only in SASC (5.5\%). It opposes the finding from Punjab, but corroborates with the finding from Lucknow. ${ }^{15,16}$

In this study, Hymenolepis nana was found to be most common helminth. Again, only from the SASC (16.7\%). It is in opposition to findings from other studies in Bihar, where Ascaris lumbricoides (80.8\%) and Ancylostoma duodenale $(18 \%)$ were found to be most prevalent. ${ }^{18,19}$ Both these study districts are quite distant from the district of the present study. On the contrary, some other studies from Dhanbad, Jharkhand and Delhi go with our result of H. nana being most prevalent. ${ }^{20,21}$ The prevalence rate of $\mathrm{H}$. nana in the study corroborates with the percentage incidence of Punjab study (17.64\%).15

Our study had certain limitations. One of it is that result concerning school children in one or two school cannot represent school children population living in the whole district. Sampling method taking a larger number of randomly selected school children of each sex for each age group is more appropriate for representation of whole districts. But, it could not be applied due to technical and time limitations.

\section{CONCLUSION}

The prevalence of intestinal parasite in slum area school is more than posh area school due to poor hygiene habits among children and poor sanitary condition of slum area school. An integrated approach to drug treatment and focused participatory hygiene education is required to control the parasite load in both the schools.

\section{REFERENCES}

[1] World Health Organisation, Geneva. Intestinal parasite: burden and trends. 2013. https://apps.who.int/ctd/intpara/burdens.htm.

[2] Chongbang R, Dongol P, Chakrawarti A, et al. Parasitic infections among children of squatter community in Dharan municipality, Sunsari, Nepal. Int J Appl Sci Biotechnol 2016;4(2):203-06.

[3] WHO. Fact sheets, Intestinal worms, Geneva. 2014.

[4] Dougre AR, Deshmukh PR, Boratne AV, et al. An approach to hygiene education among rural Indian school going children. Online Journal of Health And Allied Sciences 2007;6(4):1-6.

[5] Asemahagn MA. Parasitic infection and associated factors among the primary school children in Motta Town, Western Amhara, Ethiopia. American Journal of Public Health Research 2014;2(6):248-54.

[6] Nokes C, Grantham-McGregor SM, Sawyer AW, et al. Parasitic infection and cognitive function in school children. Proceed Roy Soc B Biol Sci 1992;247(1319):77-81.

[7] World Health Organization. Cambodia protect $75 \%$ of children against parasites, becomes first country to reach key target. 2004.

[8] Dickson R, Awasthi S, Demellweek C, et al. Anthelminthic drugs for treating worms in children: effects on growth and cognitive performance. Cochrane Database Syst Rev 2003;(2):CD000371.

[9] Chakma T, Rao PV, Tiwary RS. Prevalence of anemia and worm infestation in tribal areas of Madhya Pradesh. J Indian med Assoc 2000;98(9):567-71.

[10] Mahajan M, Mathur M, Talwar R, et al. Prevalence of intestinal parasitic infection in east Delhi. Indian J Community Med 1993;18(4):177-80.

[11] Pandey BN, Kumar D, Verma DK. Epidemiological study of parasitic infestations in rural women of Terai belt of Bihar, India. Annals of Biological Research 2013;4(10):30-3.

[12] Chandrashekhar TS, Joshi HS, Gurung M, et al. Prevalence and distribution of intestinal parasitic infestation among school children in Kaski district, Western Nepal. Journal of Medicine and Biomedical Research 2005;4(1):82-7.

[13] Sehgal R, Reddy GV, Verweij JJ, et al. Prevalence of intestinal parasitic infection among school children and pregnant women in a low socioeconomic area, Chandigarh, North India. RIF 2010;1(2):100-03. 
[14] PCD (The partnership for child development). The health and nutritional status of school children in Africa: evidence from school based health program in Ghana and Tanzania. Trans R Soc Trop Med Hyg 1998;92(3):254-61.

[15] Kaur H, Sween. Intestinal parasitic infections in children of Rajpura town, Patiala. Journal of parasitic diseases. 2007;31:56-60.

[16] Saifi MA, Wajihullah. Intestinal parasitic infestation in school children of Ujhani, Badaun. J Parasite Dis 2001;25:26-9.

[17] Khurana S, Aggarwal A, Malla N. Comparative analysis of intestinal parasitic infection in slum, rural and urban populations in and around union territory, Chandigarh. J Commun Dis 2005;37(3):239-43.
[18] Pandey BN, Mishra SK. Prevalence of intestinal parasitic infestation among tribal populations of Purnia district. J Ecobiol 2000;12:33-6.

[19] Sharma RK. Strongyloides stercoralis, Trichuris trichiura and Enterobius vermicularis infection in human population Bermo coal field area of Bihar. Bioved 2001;1:173-6.

[20] Saha DR, Gupta DN, Sengupta PG, et al. Intestinal parasitism: a childhood problem in rural Bengal. J Communi Dis 1995;27(3):170-4.

[21] Mirdha BR, Samantaray JC. Hymenolepis nana: a common cause of pediatric diarrhoea in urban slum dwellers in India. J Trop Pediatr 2002;48(6):331-4. 